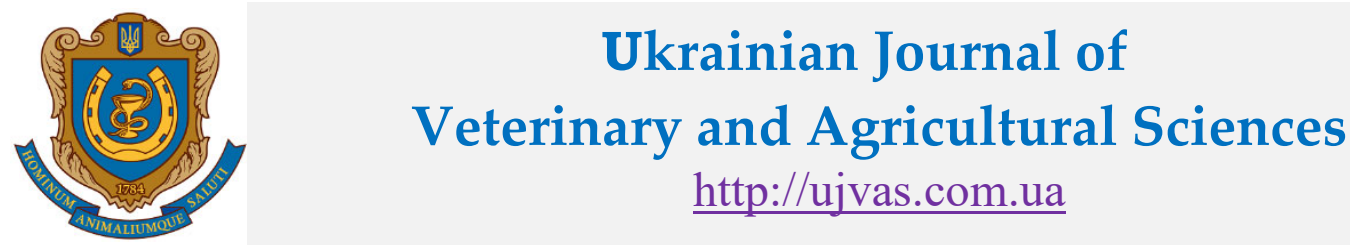

Stepan Gzhytskyi National University of Veterinary Medicine and Biotechnologies Lviv \begin{tabular}{l|l|ll} 
review article & UDC 619:618.14:618.19-002:636 & doi: 10.32718/ujvas3-2.01 & Number 2
\end{tabular}

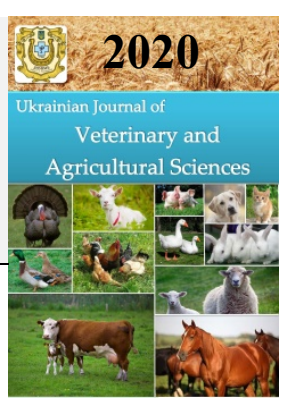

\title{
Emergency contraception using progestin drugs in domestic cats
}

\author{
A. Vasetska \\ Luhansk National Agrarian University, Slobozanska Str., 68, Starobilsk, 92703, Ukraine
}

\begin{abstract}
Article info
Received 16.03.2020

Received in revised form 20.04.2020

Accepted 21.04.2020

Correspondence author

Anastasiia Vasetska

Tel.: +38-066-591-49-56

E-mail: anastasiyavas90@gmail.com

2020 Vasetska A. This is an open-

access article distributed under the

terms of the Creative Commons

Attribution License, which permits unrestricted use, distribution, and reproduction in any medium, provided the original author and source are credited.

\section{(cc) BY}

Abstract

Today, in conditions of strict quarantine, when it is not always possible to carry out surgery in cats, some methods of emergency drug contraception can be used. Over the years, many contraceptive medications have been developed for companion animals, but many secondary adverse effects have limited their use. However, in all species, the secondary adverse effects of progesterone-type drugs limit their use and vary depending on when treatment is given in relationship to the stage of the estrous cycle. An ideal non-surgical sterilant would be safe, effective, permanent, administered as a single injection and capable of being manufactured inexpensively. Contraceptives are used for cats, as a method of renewable fertility over time for breeding animals, as a method of suppressing sexual function for animals at risk for surgery, and to prevent over populations in stray cats. The use of nonsurgical, safe and effective methods of suppression of sexual function in cats eliminates traumatization, anesthesia and complicated postoperative period in animals, which in some cases are impossible in the state of health, etc. The most common and affordable method of medical contraception is progestins, such as megestrol acetate, medroxyprogesterone acetate, proligestone (used orally or as a depot injection). These drugs are effective in inhibiting sexual function. Contraceptives for felids are available as implants, depot injections, and pills or liquid for oral administration, powder for mixing with food, or as vaccines. Regimens may differ according to the timing of first treatment, whether coinciding with the active reproductive period, preceding this period, or during anestrus. Ideally, the treatment regimen is initiated during anestrus to minimize the dose needed for reproductive suppression and to avert exposure to endogenous steroids that can cause lesions in reproductive organs.
\end{abstract}

Contents

1. Introduction

2. Conclusions

References

Key words: cats, contraception, progestin, non-surgical methods.

\section{Citation:}

Vasetska, A. (2020). Emergency contraception using progestin drugs in domestic cats. Ukrainian Journal of Veterinary and Agricultural Sciences, 3(2), 3-6.

\section{Introduction}

For many years, surgical castration has been the only reliable and permanent method of contraception in small animals. However, in many countries, discussion and even controversy surround the benefits and risks associated with these procedures (Reichler, 2009).

Over the years, many contraceptive medications have been developed. In approximately 1960, with the availability of orally active and increasingly more effective progestins in humans, efforts began to control reproduction in dogs and cats. Many types of progestins, oral or injectable, have been used for estrous control in small animals. However, in all species, the secondary adverse effects of progesterone-type drugs limit their use and vary depending on when treatment is given in relationship to the stage of the estrous cycle. An ideal non-surgical sterilant would be safe, effective, permanent, administered as a single injection and capable of being manufactured inexpensively (Struthers, 2012).

Contraceptives are used for cats, as a method of renewable fertility over time for breeding animals, as a method of suppressing sexual function for animals at risk for surgery, and to prevent over populations in stray cats
The use of non-surgical, safe and effective methods of suppression of sexual function in cats eliminates traumatization, anesthesia and complicated postoperative period in animals, which in some cases are impossible in the state of health, etc.

The most common and affordable method of medical contraception is progestins, such as megestrol acetate, medroxyprogesterone acetate, proligestone (used orally or as a depot injection). These drugs are effective in inhibiting sexual function.

However, long-term use violation of dosage and use in animals with pathology of the reproductive system and mammary gland is may associated with endometrial hyperplasia, endometrial cancer, and mammary cancer. There are methods and protocols for the safe use of progestins for cats, in which the risk of side effects is reduced.

Contraception in its broadest sense is preventing the birth of offspring while maintaining the potential for fertility. Contraception can be achieved by preventing gamete formation, conception, or implantation, as well as by disrupting pregnancy (causing resorption or abortion). Contraceptives are more widely used in females where the intricately orchestrated events leading to oogenesis, ovulation, 
gamete transport and implantation are more easily disrupted than is spermatogenesis in the male. Reproductive cyclicity and gametogenesis in both sexes can be disrupted by administrating exogenous hormones that interfere with the normal hypothalamic/pituitary/gonadal axis, prevent hormonal synthesis or release, or interfere with endocrine activity at the tissue level. Spermatogenesis also can be directed arrested by some chemicals. Fertilization can be averted by physically blocking the reproductive tract, altering the uterine milieu necessary for sperm movement, or interfering with spermegg binding necessary for fertilization (Munson, 2006).

Contraceptives for felids are available as implants, depot injections, pills or liquid for oral administration, powder for mixing with food, or as vaccines. Regimens may differ according to the timing of first treatment, whether coinciding with the active reproductive period, preceding this period, or during anestrus. Ideally, the treatment regimen is initiated during anestrus to minimize the dose needed for reproductive suppression and to avert exposure to endogenous steroids that can cause lesions in reproductive organs (Wildt et al., 1998).

\section{Progestins}

Megestrol acetate, a synthetic progestin, is a tasteless, odorless crystalline powder. Megestrol acetate is rapidly metabolized when given orally (Plumb, 2002). It stops ovulation and acts on LH and FSH production. Megestrol ace- tate is highly patented; it is 5 times stronger than natural progesterone.

Proposed mechanisms of megestrol acetate action include:

1. negative feedback on the hypothalamus and pituitary gland leading to suppression of GnRH, FSH, or LH secretion and failure of folliculogenesis and/or ovulation;

2. altered motility of the tubular tract causing failed oocyte transport and fertilization

3 . altered receptivity of the endometrium resulting in implantation failure (Munson, 2006).

Megestrol acetate (MA) is considered to be one of the older generation of drugs with high gestagenic and antigonadotropic activity but poor anti-estrogenic effects. Megestrol acetate suppressed follicular development or ovulation, suggesting that hypothalamic and pituitary suppression is not the means by which these agents effect contraception. In general, progestins promote endometrial growth and secretion, as well as smooth muscle relaxation in the uterus (Hafez et al., 2000). Therefore, altered uterine motility and endometrial receptivity are the likely mechanisms for progestin-induced contraception.

All progestin drugs that used for cats have pharmacological form of pills or drops and injection form. Its cheap costs and available in veterinarian pharmacy and zoo-shop. Specific example of such drugs that are most popular commercially available in Ukraine listed in Table 1.

Table 1

Most popular and commercially available in Ukraine progestin contraceptives

\begin{tabular}{cccc}
\hline Contraceptive & Brand name & Manufacture & Method of delivery \\
\hline & Kontric & Farmatone & Oral pills \\
& Nonoestrone & Prima-Vet & Oral pills \\
Megestrol acetate & Pillcane-5 & CEVA & Oral sugar cubes \\
& EKS-5 & AVZ & Oral drops \\
& Sexinon & O.L.KAR & Oral pills/drops \\
& Sexanet & Brovafarma & Oral/pills/drops \\
\hline \multirow{2}{*}{ Medroxyprogesterone } & Proveravet & Vetsyntes & Oral pills \\
acetate & Medropet & GiGi & Oral pills \\
& Depogestone & Biowet-Pulawy & Injection depot \\
\hline Proligetone & Covinan & Intervet & Injection depot
\end{tabular}

In all instruction for megestrol acetate drugs was written that its highly effective at suppressing estrus in queens when given at a dose of $5 \mathrm{mg} / \mathrm{cat}$ orally for 5 days and then once weekly.

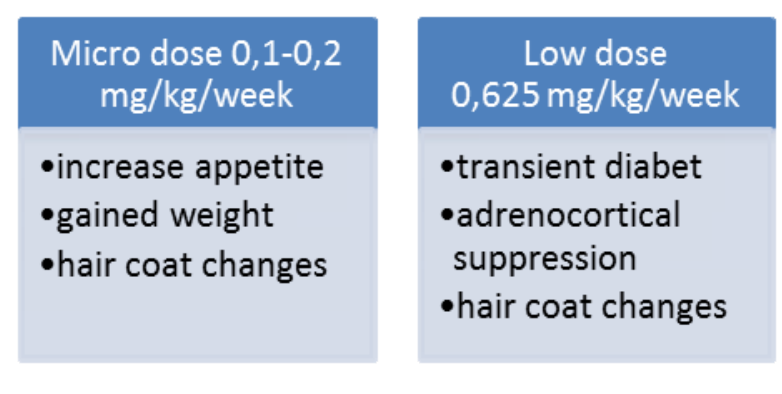

Nevertheless, after numerous studies, scientists have suggested other dosages megestrol acetate to reduce the likelihood of side effects. One of the principles of using megestrol acetate: "Low dosing for individual cat. One cat. One dose. One week" (Romagnoli, 2015).
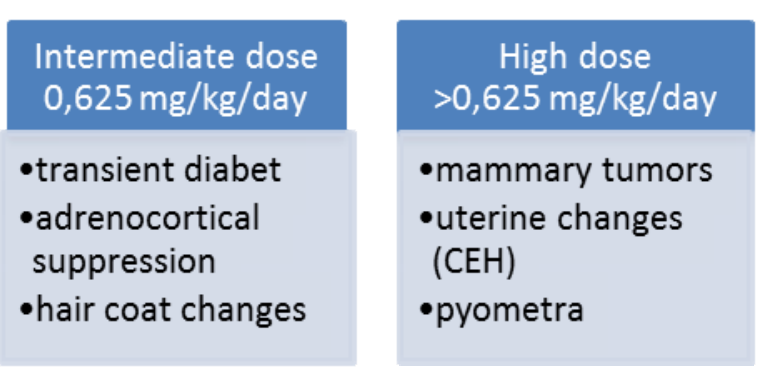

Fig. 1. Scheme of megestrol acetate dosage and side effects in cats

Treatment regimens differ depending on whether treatment is initiated during anestrus, estrus, or diestrus. In the anestrous domestic cat, an initial dose of $2.5-5 \mathrm{mg} /$ day for
3-5 days has been recommended, followed by $2.5-$ $5 \mathrm{mg} /$ week (Oen, 1977). Cats in estrus may require a higher dose (5 mg/day until estrus stops, then $2.5-5 \mathrm{mg} / \mathrm{week}$, per 
os) (Plumb, 2002). The recommended dose for diestrous cats is $2.5 \mathrm{mg}$ /day per os (Romagnoli, 2015). Treated cats should be separated from adult males for at least 1 week to assure efficacy. Recommended duration of treatment ranges from 2 to 18 months, followed by a period of normal estrous cycles before treatment is repeated (Romatowski, 1989). Most MA-treated cats return to estrus within a few days.

Reported side effects of prolonged megestrol acetate treatment in cats included: increased appetite leading to weight gain; lethargy or restlessness (Burke, 1982); marked mammary stimulation with hyperplastic and/or neoplastic changes; clinical and pathologic changes typical of diabetes mellitus (Kutzler \& Wood, 2006).

Also was proved experimentally scheme when MA was given in complex with homeopathic drugs such "Ovaryovit" and "Mastometrin" ( $5 \mathrm{mg} /$ per cat orally and IM injection $1 \mathrm{ml} /$ per cat "Ovaryovit" and "Mastometrin" 3 times per week during 6 weeks. During these study only $19 \%$ side effects on reproductive organs and mammary gland were registered (Vasetska \& Stefanyk, 2018).

Medroxyprogesterone acetate (MPA) belongs to the old generation of contraceptive agents. It is characterized by high antigonadotropic and gestagenic activity, but shows a relatively small antiestrogenic effect (Evans \& Sutton,

Table 2

Drug regimens for various progestins in cats

\begin{tabular}{|c|c|c|}
\hline Component & Treatment & References \\
\hline \multicolumn{3}{|l|}{ Progestin } \\
\hline \multirow[t]{4}{*}{ Megestrol acetate } & $\begin{array}{l}2.5-5 \mathrm{mg} / \text { day for } 3-5 \text { days } \\
2.5-5 \mathrm{mg} / \text { week }\end{array}$ & Oen E. O., 1977 \\
\hline & $\begin{array}{l}5 \mathrm{mg} / \mathrm{day} \text { until estrus stops than } \\
2.5-5 \mathrm{mg} / \text { week }\end{array}$ & Plumb D. C., 2002 \\
\hline & diestrous cats is $2.5 \mathrm{mg} /$ day & Romagnoli S., 2015 \\
\hline & $\begin{array}{l}5 \mathrm{mg} / \mathrm{cat} \text { once per month when queen has no } \\
\text { sign of estrus, during } 20 \text { months }\end{array}$ & Vasetska A., Stefanyk V., 2018 \\
\hline $\begin{array}{l}\text { Medroxyprogesterone } \\
\text { acetate }\end{array}$ & $\begin{array}{l}10 \mathrm{mg} / \mathrm{kg} \text { twice at an interval of } 24 \text { hours } \\
5 \mathrm{mg} / \mathrm{cat} \text { once per month when queen has no } \\
\text { sign of estrus, during } 20 \text { months }\end{array}$ & $\begin{array}{l}\text { Romagnoli S., Concannon P. W., } 2003 \\
\text { Vasetska A. I., Mass A. O., } 2018\end{array}$ \\
\hline
\end{tabular}

Proligestone (14a, 17 $\alpha$-propylidene-dioxy progesterone) is a unique progestin with weaker progestational activity than other synthetic progestins (Plumb, 2002). Proligestone is marketed in Europe and Ukraine (Covinan, Intervet) as an injectable canine and feline contraceptive. The manufacturer claims that it is safe to use for prevention, delay or suppression of estrus when given to female dogs at an initial dose of 10-30 $\mathrm{mg} / \mathrm{kg} \mathrm{SQ}$, with repeated administration 3 and 7 months later. It can also be given to female cats $(1 \mathrm{ml}$ subcutaneously), causing estrus suppression for about 6.5 months. In clinical trials, this regimen did not promote development of uterine disease or mammary tumors (Kutzler \& Wood, 2006).

The use of exogenous progestins however is associated with several important side effects (Max \& Jurka, 2006). These are most frequently observed in the uterus, such as endometrial cystic degeneration, also referred to as $\mathrm{CEH}-$ et al., 2009). While estrogens stimulate progesterone receptors in the endometrium, progesterone and synthetic progestins stimulate uterine glands to secretion, causing hyperplasia and hypertrophy, and consequently the formation of cysts of various sizes, which often is accompanied by infiltration cystic endometrial hyperplasia (Kim \& Kim, 2005; Keskin
1989). It is slowly metabolised in the liver. After a single administration during the proestrus MPA blocks the estrous cycle for on average 6 months. However, a lack of heat was also described in some queens up to 26 months after application. For this reason, MPA administered parenterally should not be used in valuable breeding animals. When administered orally, this compound is effective for suppression of heat during proestrus as well as for temporary postponement of heat (Max \& Jurka, 2006).

However, proliferations of endometrium and mammary glands, leading to developments of infertility and mammary hyperplasia are the adverse effects of the exogenous progestins (Chatdarong et al., 2005). A single administration of depot MPA (at least $10 \mathrm{mg} / \mathrm{kg}$ ) has shown to develop fibroadenomatous mammary hyperplasia in the cats (Loretti et al., 2005). However, the hyperplasia of the mammary tissue can be subsided after treatment with aglepristone, a progesterone receptor blocker $(10 \mathrm{mg} / \mathrm{kg}$ twice at an interval of 24 hours) (Romagnoli \& Concannon, 2003). Also proposed new effective scheme of MPA $5 \mathrm{mg} /$ cat once per month when queen has no sign of estrus, during 20 months. During treatment in experimental study side effects was in $17 \%$ of cats and this side effects were reversible did not require surgery (Vasetska \& Mass, 2018). of leukocytes. Prolonged secretory activity in combination with infection of the uterine cavity (especially in immunocompromised animals), may lead to the development of endometritis/pyometra complex. Furthermore, in dogs and cats mammary tumors, hyperglycemia and acromegaly were observed after repeated progestin administrations (Fagerstone et al., 2010).

Progestins can stimulate local secretion of growth hormone by the mammary glands, inter alia, via insulin-like growth factor IGF-1, which induces proliferative processes (Conneely et al., 2003). One of them is feline fibroadenomatosis, the rapid, but not malignant, proliferation of cells in the ducts and stroma of the mammary glands which is considered to be hyperplastic/dysplastic changes. The condition may be a result of natural progesteronic activity and sometimes arises in cats treated with progestins, especially longacting formulations (Jurka \& Max, 2009). Other possible side effects are adrenal dysfunction, hepatitis, developmental disorders, withholding of labor, behavioral changes and local skin alterations. Simultaneously with a decrease in the concentration of the administered progestinand the increase in prolactin secretion, signs of pseudopregnancy may be observed (Cathey \& Memon, 2010). 


\section{Conclusions}

However, gonadectomy remains the procedure of choice for permanent sterilization of domestic cats. However, no single method of reproduction control will be a panacea for the suppression reproductive function and contraception problem in cats. Commercial development of products for hormonal down-regulation with exogenous steroid hormones to provide nonsurgical alternatives for contraception and sterilization.

Undoubtedly, each progestogen has its own side effects. Nevertheless, it is possible to avoid many side effects with the proper use of these medications. Under quarantine, nonsurgical methods of contraception can become an alternative to surgery.

\section{References}

Burke, T. J. (1982). Pharmacologic control of estrus in the bitch and queen. Vet Clin North Am Small Anim Pract., 12(1), 7984. doi: 10.1016/s0195-5616(82)50007-1.

Cathey, M., \& Memon, M. A., (2010). Nonsurgical methods of contraception in dogs and cats: Where are we now? Vet. Med., $105,12-17 . \quad \mathrm{https}: / / \mathrm{www} . \mathrm{dvm} 360 . \mathrm{com} / \mathrm{view} /$ nonsurgicalmethods-contraception-dogs-and-cats-where-are-we-now.

Chatdarong, K., Rungsipipat, A., Axnér, E., \& Linde Forsberg, C. (2005). Hysterographic appearance and uterine histology at different stages of the reproductive cycle and alter progestagen treatment in the domestic cat. Theriogenology, 64(1), 12-29. doi: 10.1016/j.theriogenology.2004.10.018.

Conneely, M. O., Mulac-Jericevic, B., \& Lydon, P. J. (2003). Progesterone-dependent regulation of female reproductive activity by two distinct progesterone receptor isoforms. Steroids, 68(10-13), 771-778. doi: 10.1016/S0039-128X(03)00126-0.

Evans, J. M., \& Sutton, J. D. (1989). The use of hormones, especially gestagens, to control oestrus in bitches. J. Reprod. Fertil. Supp., 39, 163-173. http://agris.fao.org/agris-search/ search.do?recordID $=$ GB9013627.

Fagerstone, K. A., Miller, L. A., Killian, G., \& Yoder, C. A. (2010). Review of issues concerning the use of reproductive inhibitors, with particular emphasis on resolving human wildlife conflicts in North America. Integrative Zoology, 5(1), 1530. doi: 10.1111/j.1749-4877.2010.00185.x.

Hafez, E. S. E., Jainudeen, M. R., \& Rosnina, Y. (2000). Hormones, growth factors, and reproduction. In: Hafez ESE, Hafez B, editors. Reproduction in farm animals. Philadelphia, PA: Lippincott Williams and Wilkins, 33-54. doi: 10.1002/9781119265306.ch3.

Jurka, P., \& Max, A., (2009). Treatment of fibroadenomatosis in 14 cats with aglepristone. Vet. Rec., 165(22), 657-660. doi: 10.1136/vr.165.22.657.
Keskin, A., Yilmazbas, G., Yilmaz, R., Ozyigit, M. O., \& Gumen, A. (2009). Pathological abnormalities after long-term administration of medroxyprogesterone acetate in a queen. J. Feline Med. Surg., 11(6), 518-521. doi: 10.1016/j.jfms.2008.10.006.

Kim, K. S., \& Kim, O. (2005). Cystic endometrial hyperplasia and endometritis in a $\mathrm{dog}$ following prolonged treatment of medroxyprogesterone acetate. J. Vet. Sci., 6, 81-82.

Kutzler, M., \& Wood, A. (2006). Non-surgical methods of contraception and sterilization. Theriogenology, 66(3), 514-525. doi: 10.1016/j.theriogenology.2006.04.014.

Loretti, A. P., IIha, M. R. S., Ordás, J., \& Martín de las Mulas, J. (2005). Clinical, pathological and immunohistochemical study of feline mammary fibroepithelial hyperplasia following a single injection of depot medroxyprogesterone acetate. $J$ Feline Med Surg, 7, 43-52. doi: 10.1016/j.jfms.2004.05.002.

Max, A., \& Jurka, P. (2006). Skutki uboczne stosowania gestagenów u psów i kotów [Adverse effects after administration of gestagens in dogs and cats]. Med. Weter., 62, 508-511 (in Polish).

Munson, L. (2006). Contraception in felids. Theriogenology, 66(1), 126-134. doi: 10.1016/j.theriogenology.2006.03.016.

Oen, E. O. (1977). The oral administration of megestrol acetate to postpone oestrus in cats. Nord Vet Med, 29(6), 287-291. https://europepmc.org/article/med/896408.

Plumb, D. C. (2002). Veterinary Drug Handbook, 4th ed., Ames: Iowa State Press. https://www.ncbi.nlm.nih.gov/ pmc/articles/PMC372247.

Romagnoli, S., \& Concannon, P. W. (2003). Clinical use of progestins in bitches and queens: a review. In: Concannon PW, England G, Verstegen J, Linde-Forsberg C, eds. Recent advance in small animal reproduction. Ithaca NY.

Reichler, I. M. (2009). Gonadectomy in cats and dogs: a review of risk and benefits. Reprod Dom Anim, 44(2), 29-35. doi: 10.1111/j.1439-0531.2009.01437.x.

Romagnoli, S. (2015). Progestins to control feline reproduction: Historical abuse of high doses and potentially safe use of low doses. J Feline Med Surg., 17(9), 743-752. doi: $10.1177 / 1098612 X 15594987$.

Romatowski, J. (1989). Use of megestrol acetate in cats. J Am Vet Med Assoc., 194, 700-702.

Struthers, R. S. (2012). Gonadotrophinreleasing hormone targeting for gonadotroph ablation: an approach to non-surgical sterilization. Repro Domest Anim, 47(4), 233-238. doi: 10.1111/j.1439-0531.2012.02081.x.

Vasetska, A., \& Mass, A. (2018). Method of medical contraception of female cats. Patent № 122925. Ukraine. published 25.01.2018, Bull. № 2 (in Ukrainian).

Vasetska, A., \& Stefanyk, V. (2018). Method of comlex medicamental contraception in females of domestic animals. Scientific Messenger of LNU of Veterinary Medicine and Biotechnologies. Series: Veterinary Sciences, 20(83), 352-356. doi: $10.15421 /$ nvlvet8370.

Wildt, D. E., Brown, J. L., Swanson, W. F., Knobil, E., \& Neill, J. D. (1998). Encyclopedia of reproduction. Reproduction in felids. New York, NY: Academic Press, 497-510. 